\title{
CENTRAL EUROPE OR EAST-CENTRAL EUROPE?
}

Doland lies in Europe - this assertion reflects not only its geographical location but 1 is also related to the fact that it is part of "European culture", the content of which has been discussed extensively in an attempt to point to the "European identity" (or the identity of states or even nations that belong to the European Union), usually associated with three aspects, Greek philosophy (but in what sense?), Roman law (as "codified" on the order of the Byzantine emperor, Justinian I the Great?) and Christianity (but in which of its denominations?), as well as differences that potentially exist between its various fragments. The differences were captured by observing the specific character of the Germanic and Romance peoples for example, but also a somewhat distinct nature of the Slavs and other peoples, different in some measure from them - despite the differences between the first two - and having perhaps a different history shaped by a closer relationship with the East. And therefore cultural aspects, and most likely political aspects as well, are taken into consideration in discussions on such topics as differences between Western (Latin) and Eastern (Greek) Christianity, which predate the $11^{\text {th }}$ century; they are further taken into consideration in debates on Western Europe, as allegedly different from "Central Europe, or perhaps even "East Central Europe", which, according to the latter approach, are more closely related to the East. However, in connection to the latter issue it is worth considering a relatively recent experience related to the fact that some of the countries (nations), while "geographically Central European", belonged to the "Soviet bloc"; for this experience has become a peculiar context for a constantly maintained distinction: the name "Central Europe" was to denote a part of Europe different from both "Western Europe" and "Eastern Europe". Among the three best known literary figures (Milan Kundera, Czesław Miłosz and István Bibó) who came from countries of the "Soviet bloc" (or "Eastern bloc", or "people's democracies" under the control of the Soviet Union after World War II) and who were probably most instrumental in promoting this name, especially in the 1980s, it was particularly the first who preferred it to the name "East Central Europe", as this latter name implied a relative proximity of Central Europe to the East, as opposed to the West. Nevertheless even Kundera pointed out the - primarily cultural - separateness of this part of 
Europe, or more specifically, of the peoples living in its territory, compared to those peoples who remain further to the West as well as those peoples who remain further to the East of the territories (peoples) associated with Central or (after all) East Central Europe. According to Kundera it is only in a world that maintains a cultural dimension that Central Europe can still defend its identity, still be seen as it is. ${ }^{1}$ Miłosz in turn said that the ways of feeling and thinking of inhabitants of East Central Europe must suffice for drawing mental lines which seem to be more durable than the borders of the states ${ }^{2}$.

While referring the readers to relatively numerous texts discussing to decades-long debates among geographers and historians regarding the borders and the essence of "Central Europe", debates that occasionally touch upon aspects of the culture specific to the peoples inhabiting the variously defined territory, as well as debates over the claim put forward by some discussants about the "kidnapping of Central Europe by the East" after 2015 at the latest, ${ }^{3}$ we present articles written by Authors representing a number of countries, whether considered to be part of Central or of East Central Europe. The texts, prepared by scholars from Lithuania, the Czech Republic, Slovakia, Hungary, Ukraine, Russia and finally Poland, may reveal the problematic nature of Oskar Halecki's claim whereby the term "East Central Europe" denotes "border territories of Western civilization", which are after all heterogeneous; it will certainly also make evident the complexity inherent in the question of the participation of the peoples inhabiting these lands in, after all, the Western cultural and political area.

Bogdan Szlachta

1 The tragedy of Central Europe, The New York Review of Books, April 24, 1984, pp. 33-38, transl. by E. White, p. 38.

2 C. Miłosz, "About Our Europe", in R. Kostrzewa (ed.), Between East and West: Writings from Kultura, New York, p. 100.

3 See K. Puto, Nowa Europa Środkowa jest projektem nieudolnym, at <http://krytykapolityczna.pl/ felietony/kaja-puto/wschod-porwany-przez-zachod>, 12 July 2018), English translation available at $<$ http://politicalcritique.org/cee/2017/a-kidnapped-east/>, 11 March 2019). The article also discusses the Lisbon meeting of 1988 when the idea of Central Europe was defended among others by Czesław Miłosz and György Konrád, arguing that the West had been "kidnapped by the East" there, although it was Central Europe itself that adhered to "Western" or "European" values, while the West was only "descending into commercialism". This view was apparently criticized by Russians (Josif Brodski, Tatiana Tolstoy), according to whom the project of Central Europe "is clearly symbolic and has no realistic substance." Note that according to the English translation of K. Puto's article Miłosz and Konrád said that they were "an East kidnapped by the West". This is clearly a mistake: as the names East and West have been swapped compared to the Polish original. 